\title{
Primary results of a bat survey in south-western Ethiopia, with a new Ethiopian record of Kerivoula lanosa (Chiroptera: Vespertilionidae)
}

\author{
Sergei V. Kruskop \& Leonid A. Lavrenchenko
}

\begin{abstract}
A short-term bat survey was conducted in spring, 2007, by the Joint Ethiopian-Russian Biological Expedition in the Mejangra Zone of the Gambela Peoples' National Regional State, southwestern Ethiopia. The area studied was adjacent to the Godare forest massif, one of the most lowland forests of Ethiopia. About 100 individuals of fifteen bat species from ten genera and six families were captured. Together with species recorded in 2000, the total bat community in Godare forest includes at least 19 species. One of the most important records is the third capture of Kerivoula lanosa from Ethiopia; the two previous captures in Ethiopia were more than a hundred years ago. The capture of Myotis bocagei also was only the third record from the country. Individuals of Rhinolophus and Miniopterus belong to undetermined species.
\end{abstract}

KEY WORDS: Chiroptera, Kerivoula, Miniopterus, Rhinolophus, Myotis, Ethiopia, new records.

SergeiV. Kruskop [kruskop@zmmu.msu.ru], Zoological Museum of Moscow State University, Ul. Bolshaya Nikitskaya 6, Moscow 125009, Russia; Leonid A. Lavrenchenko [lavrenchenko@sevin.ru], A.N. Severtsov Institute of Ecology and Evolution RAS, Leninskii pr. 33, Moscow 119071, Russia.

\section{Предварительные результаты изучения рукокрылых на юго-западе Эфиопии и новая эфиопская находка Kerivoula lanosa (Chiroptera: Vespertilionidae)}

\author{
С.В. Крускоп, Л.А. Лавренченко
}

РЕЗЮМЕ. Непродолжительные исследования фауны рукокрылых в зоне Медженгр Демократической Национальной области Гамбела (юго-запад Эфиопии) были проведены весной 2007 г. в рамках работы совместной Российско-Эфиопской биологической экспедиции. Обследованная территория находится на границе лесного массива Годаре, одного из наиболее низинных лесов в Эфиопии (высота над уровнем моря около 1300 м). Было отловлено около ста особей пятнадцати видов рукокрылых из десяти родов шести семейств. Включая виды, отмеченные в 2000 г., в целом сообщество рукокрылых леса Годаре включает не менее 19 видов. Одна из наиболее значимых находок - третий случай поимки на территории Эфиопии украшенного гладконоса, Kerivoula lanosa; две предыдущие находки были сделаны более ста лет назад. Поимка Myotis bocagei так же представляет собой всего лишь третью находку вида на территории страны. Пойманные особи родов Rhinolophus и Miniopterus принадлежат к пока не установленным видам.

КЛЮЧЕВЫЕ СЛОВА. Рукокрылые, Kerivoula, Miniopterus, Rhinolophus, Myotis, Эфиопия, новые находки.

\section{Introduction}

Even brief surveys of local bat faunas provide information about bat distribution, abundance and environmental preferences, forming the basis for further conservation activities (Fahr \& Ebigbo, 2003; Decher \& Fahr, 2007). They are especially important in the case of poorly investigated areas with specific natural conditions. The primary forests of south-western Ethiopia undeniably represent such an area, differing from all neighboring territories and the rest of Ethiopia.

The Godare forest massif is in the most eastern part of Gambela Province, bordering the remains of more highland forests to the north and east and with savannahs in west. Bats of this forested area were very briefly surveyed for the first time in 2000 (Lavrenchenko et al., 2004), when nine species were recorded. However, results of that survey suggested a more diverse bat community.

In spring 2007, a small mammal survey was conducted by the Ethiopian-Russian Joint Biological Expedition in the vicinity of Bishan Wak'a Lake (Meti area of the Mejangra zone, Gambela; N 7º17', E 35 ${ }^{\circ} 16^{\prime}$; altitude 1350-1390 m ASL), on the border of Godare forest massif. About 100 individuals of bats were captured, representing at least fifteen species from 10 gen- 
era and six families. Amongst them, an adult female of the woolly bat (Kerivoula) was captured, only the third record of the genus for Ethiopia and the first from the south-west of the country.

While there is some progress in the understanding of Asian Kerivoula (Francis et al., 2007), the African branch of the genus remains poorly investigated. Infrequent captures and rarity of museum specimens inhibit both the investigation of taxonomic relationships between named forms and ecological research, obscuring environmental preferences of this or that species.

\section{Material and methods}

The territory on which the investigations were conducted is situated about $23 \mathrm{~km} \mathrm{~W}$ from Tepi at relatively low elevations (1350-1390 m ASL). It was formerly part of an evergreen tropical forest massif known as Godare Forest. Now most of the study area is covered with coffee plantations (Tepi coffee farm) usually with canopy trees retained to provide shadow over the coffee crop. These plantations are divided by variable patches of pastures and primary and secondary growth. The largest water source in the area is Bishan Wak'a Lake - an almost round, flowing lake about $1.5 \mathrm{~km}$ in diameter, surrounded by a circle of primary forest.

All the bat research was restricted to that locality, from 31 March to 7 May. Bats were observed during the evening, usually between sunset and 21.30-22.00, several times also after midnight or in the morning hours up to sunrise. All the available biotopes were sampled, including variably disturbed primary forest, secondary growth, riverine biotopes, road, growth edges and coffee plantations. Observations were conducted visually with the help of electric lanterns, and acoustically by the use of narrow-band heterodyne ultrasound detector D100 (Pettersson Elektronik AB, Sweden), and accompanied with the capture of selected individuals using the flap-trap (Borisenko, 1999). Some individuals were captured with the use of typical nylon mist-nets ( trapping effort of this type of trap was relatively small, amounting to only 43 hours/net.

All the captured individuals were examined to determine sex, age and physiological condition. Selected specimens of all species captured were collected for further investigation, including of verification of their taxonomic position and status. Voucher specimens were fixed in alcohol (70\% ethanol) or 4\% formaldehyde, or prepared as a dry skin and skeleton. Extra bat individuals were released after the external examination in the same place in which they were captured. Voucher specimens were taken for the investigation to the Zoological Museum of Moscow State University. Acronyms of depositories of the processed collections are as follows: ZMMU - Zoological Museum of Moscow State University; ROM Royal Ontario Museum, Toronto; MHNG - Natural History Museum of Geneva; ZIN - Zoological Institute of Russian Academy of Sciences, St. Petersburg.
For all but three voucher specimens DNA barcodes (sequences of the 5'-fragment of cox-1 mitochondrial gene, up to $658 \mathrm{bp}$ ) were made as part of the Barcoding of life project [http://barcodinglife.com], forming basis for further molecular studies. A standard cocktail of primers acceptable for various mammalian species (Ivanova et al., 2007) was used to get PCR-products of the 5'-fragment of cox-1 (cytochrome c oxidase second subunit) mitochondrial gene (up to $658 \mathrm{bp}$ ). Analogous data from Kenyan bats were used for comparison. The Kimura 2 parameters model of the neighbour-joining method was accepted for grouping data. More detailed analysis of Ethiopian and Kenyan bat DNA barcodes is ongoing (Borisenko, in prep.).

\section{Results}

Thirteen species of insectivorous bats, from five different families, and two species of fruit bats were found. Previously published records from Godare forest (Lavrenchenko et al., 2004) include two more insectivorous bats and two fruit bats, making the overall bat diversity comparable to that of West African tropical forests (e.g., Fahr \& Ebigbo, 2003).

\section{Kerivoula lanosa}

The new record of the wooly bat should be the most important result of the given survey. A single adult female of $K$. lanos $a$ was captured by the flap-trap on 30 April. Only two localities of woolly bats were previously known from Ethiopia: one in northern Ethiopia in the Simien mountains, and the second from the Great Rift Valley somewhere north of Lake Abaya (Largen et al., 1974; Yalden et al., 1996). Both records were made more than hundred years ago, and each was described as a distinct species, K. eriophora (Heuglin, 1877) and $K$. harrisoni Thomas, 1901, respectively. Our record was made at least $320 \mathrm{~km}$ west from the more southern previously published locality of the genus in Ethiopia (Fig. 1).

According to the latest checklist (Simmons, 2005) there are presumed to be seven African species of Kerivoula. Two of them, K. phalaena and K. cuprosa, were not documented for East Africa. Two species occur in Ethiopia. One of them, K. eriophora, is known only from type locality in northern Ethiopia and once was supposed to be a senior synonym for $K$. africana (Hayman \& Hill, 1971); in his turn Kock (1984) concluded that $K$. eriophora cannot be conspecific with $K$. africana and belongs to "lanosa" species group. Based on the description and measurements of the only known $K$. eriophora specimen, Yalden et al. (1996) suggest that this form is conspecific with $K$. lanosa and a senior name for $K$. l. harrisoni. Nevertheless, the northern Ethiopian specimen is still usually treated as uncertain. $K$. harrisoni is now usually thought to be a subspecies of $K$. lanosa (Koopman, 1994; Simmons, 2005). 


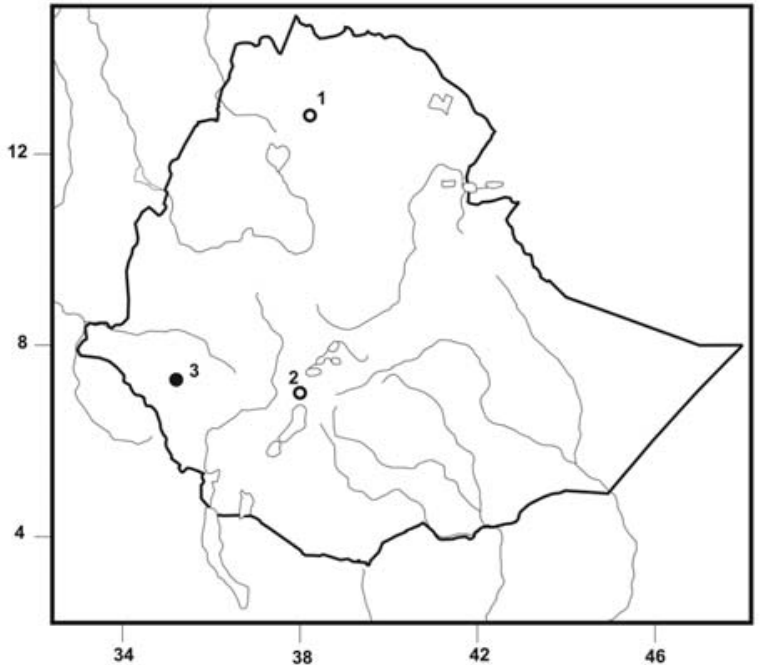

Figure 1. Localities of Kerivoula records in Ethiopia: 1 type locality of $K$. eriophora; 2 - type locality of $K$. harriso$n i ; 3$ - locality of our field work in Godare forest.

The following specimens were used as comparative material: K. lanosa muscilla - male and female from Cote d'Ivoire (types of $K$. l. bellula, MNHG-965.038, 965.039), female from Nigeria (ROM-86938); $K$. $l$. harrisoni - male from Kenya (ROM-48531); K. argentata - male from Kenya (ROM-36421); K. smithi male from Kenya (ROM-48495); K. phalaena - male from Rwanda (ROM-59191).

Selected measurements of our specimen from Godare (ZMMU S-181514) are as follows: forearm: 32.7 $\mathrm{mm}$, head and body length: $41 \mathrm{~mm}$, tail length: 35.5 $\mathrm{mm}$, hind foot: $6.4 \mathrm{~mm}$, condylocanine length: 11.77 mm, mastoid width: $7.17 \mathrm{~mm}$, upper tooth row: 5.30 $\mathrm{mm}$, width between upper canines: $3.16 \mathrm{~mm}$, lower tooth row: $5.68 \mathrm{~mm}$. Externally this individual looks very similar to the specimen of $K$. $l$. harrisoni from Kenya, having relatively dark, brown dorsal fur frosted with long very pale-silver hair tips, dark brown ventral under fur and a well developed fringe of hair on the uropatagium. However our specimen has some minor difference. Its dorsal fur has shorter silver tips to the guard hairs; it also looks paler than in $K$. l. harrisoni because of presence of wide brown bands on the hairs. There is a visible difference in pigmentation of the ears: they well pigmented in the ROM specimen and colorless in our individual. West African specimens of $K$. lanosa seem to be somewhat smaller and paler than both Godare and Kenyan specimens. The specimen of $K$. smithi is similar in size but possesses almost no fur or fringe on tail membrane; its coloration on both back and belly looks darker because of distinctly shorter and more yellowish hair tips. K. argentata has larger proportions and is distinctly paler in color, almost white ventrally. Cranial proportions of the new specimen correspond well with all measured skulls of $K$. lanosa as well as with published measurements of Kenyan speci- mens and of the K. eriophora co-type (Yalden et al., 1996). We did not see any specimens of $K$. africana, but according to the literature this species is smaller and lacks the fringe on the tail membrane (Koopman, 1994; Yalden et al., 1996). Thus we can assign the Godare woolly bat to $K$. lanosa, and it is to some extent intermediate between $K$. l. harrisoni and K. l. muscilla; its allocation to a definite geographic form needs investigation of additional material.

Our specimen was captured on the border between the coffee plantation and a small triangular patch of primary growth. At least one animal of the same species was observed in the same place two days later. In both cases animals were observed about one and half hours after sunset, flying slowly but extremely maneuverable over the coffee trees and under the large tree growing nearby, usually keeping very close (about 5-30 centimeters) to tree trunks and to canopies. The tendency to fly very close to obstacles or even between them makes woolly bats very hard to capture with the flap trap, the same habit gives them the ability to escape mist nets. This is one of the reasons why Kerivoula are so rare in scientific collections. African woolly bats and particularly K. lanosa are sometimes thought to be more characteristic of savannah woodlands (Taylor, 2000); however according to Grubb et al. (1998) and Fahr \& Ebigbo (2003), in West Africa this species seems to be more typical of forests. Our specimen came from relatively humid forest.

Observed specimens emitted very low intensity, frequency-modulated, echolocation calls, detected at about $100 \mathrm{kHz}$ and over, which is similar to characteristics known for Asian woolly bats (Kingston et al., 1999) and corresponds to the ecological niche of a leaf-gleaner or species foraging in highly cluttered space (Norberg, 1994).

\section{Other species}

In the direct vicinity of Bishan Wak'a, fruit bats were represented by Micropteropus pusillus and Rousettus aegyptiacus. Both species seem to be common and abundant, being captured and observed many times during the field work. One specimen of Epomophorus sp. was observed but not captured; probably it was $E$. gambianus, which was previously recorded for Godare forest (Lavrenchenko et al., 2004). The list of insectivorous bats includes, besides Kerivoula, Nycteris hispida, Rhinolophus sp., Triaenops persicus, Miniopterus sp., Myotis scotti, M. bocagei, M. welwitschii, Pipistrellus cf. aero, $P$. rusticus, Neoromicia guineensis, $N$. cf. nanus and Scotophilus dinganii. Undetermined freetailed bats from Molossidae family were detected by their echolocation calls. Micropteropus pusillus, Triaenops persicus, Neoromicia cf. nanus, N. guineensis, and Scotophylus dinganii were the most common and abundant amongst observed bats.

Most of the above listed species are already known for Gambela Province (Largen et al., 1974) and even 


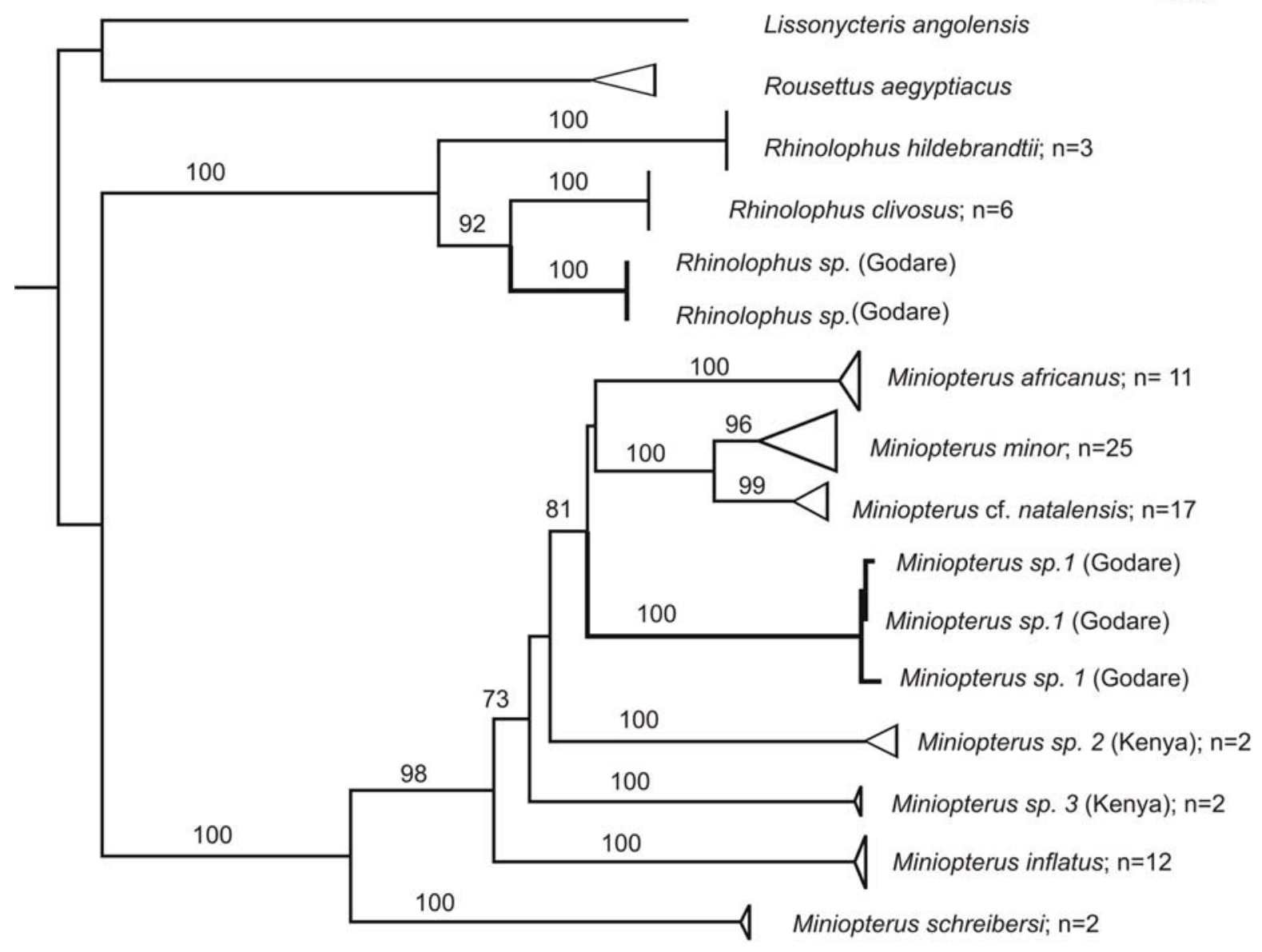

Figure 2. Kimura 2 parameter tree for East African Miniopterus and some Rhinolophus; fruit bats were taken as outgroup; bootstraps over $70 \%$ calculated from 1000 replicas are mentioned over appropriate branches.

for Godare forest (Lavrenchenko et al., 2004). For the Ethiopian endemic Myotis scotti our record is new; however, there is a previous known locality less than 30 $\mathrm{km}$ eastward, on the Beko River in the vicinity of Tepi (Lavrenchenko et al., 2004). Thus the record of major faunistic interest is $M$. bocagei. This species, not rare in the East Africa (Kingdon, 1974), has been previously found in Ethiopia only three times, in Addis-Ababa (Demeter \& Topal, 1982), near Arba Minch and at Djala (Yalden et al., 1996). During our observations, Bocage's mouse-eared bat was common on and nearby Bishan Wak' a Lake. Possibly its habit of hunting over water has led to it being under-recorded.

Both captured horseshoe bats demonstrate qualitative features, such as definitely hastate lancet, relatively narrow horseshoe not covering the whole muzzle, and lacking of the small upper premolars, which allocate them to Rh. clivosus (Csorba et al., 2003). However these individuals compared with reference material in the Royal Ontario Museum and Moscow Zoological Museum, look unlike other Rh. clivosus from Ethiopia and Kenya, especially in coloration which is greatly similar to that of Rh. alcyone from West Africa. According to the preliminary results of cox 1 gene analysis, these two specimens lie at a distance from Kenyan ones close to species level (average Kimura distance $4.77 \%$, observed distance $4.57 \%$; Fig. 2).

Three captured specimens of medium-size Miniopterus were compared with other African bent-winged bats in ZMMU and ROM collections. They demonstrate similarity with $M$. minor in fur structure and coloration, but resemble $M$. natalensis in external and cranial size. Average Kimura distances between newly found cox I haplotypes and the clade comprising Miniopterus natalensis, M. minor, and M. africanus from Kenya is $9.78 \%$ (observed distance $8.93 \%$; Fig. 2).

\section{Discussion}

Summarizing results of this survey and previous data, we can speak about the bat community containing at least 19 species. Insectivorous bats are represented, as it was already mentioned, by majority of known ecological forms: gleaners, trawlers and aerial hawkers 
(e.g., Schnitzler \& Kalko, 1998; Kruskop, 1999). Foliage gleaners are represented by Kerivoula lanosa, ground hovering gleaners by Nycteris hispida. Potentially gleaning behavior could be expected in Myotis welwitschii, however in our observations it seems to be a highly maneuverable aerial hawker. Amongst other members of this ecological group, Neoromicia cf. $n a-$ nus, $N$. guineensis and probably Rhinolophus sp. exploit highly cluttered space between growths, while both true Pipistrellus, Myotis scotti and Triaenops persicus use edges of the growth, ecologically comparable to other typical pipistrelles, whiskered bats and large serotines respectively. One of the most interesting aspects is the foraging behavior of $N$. cf. nanus, which exploits the periphery of canopies and bushes, often seen flying close to vegetation. Maximum energy of the echolocation call of this species was at over $70 \mathrm{kHz}$, which does not correspond to published data on $N$. nanus (Taylor, 2000). Scotophilus dingani, Miniopterus natalensis and the undetermined free-tailed bat represent typical high-speed hawkers, exploiting uncluttered space. Finally, Myotis bocagei demonstrate foraging behavior almost identical to that of $M$. daubentonii and similar forms (Kalko \& Schnitzler, 1989), of a typical trawler or water gleaner. Thus, in comparison to other palaeotropical bat communities, we were missing only two ecological forms, namely nectarivorous and carnivorous bats. In tropical Africa these types are represented by the fruit batMegaloglossus woermanni; by giant slit-faced bat Nycteris grandis and probably Cardioderma cor (Norberg \& Fenton, 1988) Taking into account the overall richness of this community, these elements could probably be found during further research.

In respect of environment type, revealed fauna mainly consist of species with variable biotopical preferences, living both in forests and open areas. According to Grubb et al. (1998) Micropteropus pusillus and Neoromicia guineensis are mainly inhabitants of savannah woodlands (and previously both species were known in Ethiopia from such habitats); while Nycteris hispida thought to be mainly forest species. Neoromicia nanus, treated as a savannah form by Taylor (2000), more probably inhabits a high variety of biotopes (Grubb et al., 1998). In Godare according to our survey this species usually exploits more or less forest habitats. Scotophilus dinganii is thought to be a species of savannah woodlands (Taylor, 2000), but it actually forages in open patches. So it probably does not live in thick forests, and penetrates into forested areas on the heels of roads and agrocenosis. As was said, Kerivoula lanosa probably can exploit both forests and open woodlands, but in Godare it seems to be a real forest species. Finally, Myotis bocagei, according to Rosevear (1965), prefers moist forests; however in connection to its foraging behavior this species depends mainly on open water surface and less from the neighboring landscape.

We can suppose that savannah faunal elements may penetrate into forest massifs through clearings and roads and thus depend on anthropogenous transformation of the landscape. Retaining more or less untouched patches, even small, of primary forest vegetation allowed the forest bat fauna to survive in the zone of coffee planting. However we did not observed foraging bats either forest or eurytopic species - in places of continuous plantations with greatly destroyed forest cover.

As for outstanding taxonomic questions, the identities of Rhinolophus and Miniopterus remain problematic. Five species of Miniopterus usually thought to occur in East Africa (Simmons, 2005), however it is possible that there are still present some undescribed forms (Appleton et al., 2004). Number of horseshoe bats known for East and North-East Africa is higher: about twelve species (Simmons, 2005). Rhinolophus clivosus itself represents a highly complex morphologically variable taxon (Cotterill, 2002; Csorba et al., 2003) which actually may include more then one species. In any case both horseshoe bats and bent-wing bats are members of taxonomically problematic groups, and identification of the Godare specimens need further and more comprehensive investigation of comparative material and molecular data.

ACKNOWLEDGEMENTS. We would like to thank the Manager Office and staff of the Tepi Coffee Plantation for the use of the Plantation buildings and equipment. We are especially indebted to our Project Coordinators Dr. Andrei Darkov (Joint Ethiopian-Russian Biological Expedition, Second Phase - JERBE II) and Ato Girma Yosef (Ethiopian Science and Technology Commission) for management of the expedition in the field and in Addis Ababa. The access to the collections of the Royal Ontario Museum was kindly provided to the first author by Dr. Judith Eger. We are sincerely grateful to Dr. Alex Borisenko, Dr. Nataly Ivanova and director of Canadian Centre for DNA Barcoding (Guelph, Canada) Dr. Paul Hebert for preliminary molecular analysis of Godare animals. We also would like to express our thanks to Dr. Ivan Kuzmin (Centers for Disease Control and Prevention, Atlanta, USA) who provided his Kenyan material for comparison, and Dr. Vladimir Lebedev for his help in calculating molecular distances and building dendrograms for Miniopterus and Rhinolophus.

\section{References}

Appleton B.R., McKenzie J.A. \& Christidis L. 2004. Molecular systematics and biogeography of the bent-wing bat complex Miniopterus schreibersii (Kuhl, 1817) (Chiroptera: Vespertilionidae) // Molecular Phylogenetics and Evolution. Vol.31. No.2. P.431-439.

Borisenko A.V. 1999. [A mobile trap for capturing bats in flight] // Plecotus et al. Vol.2. P.10-19 [in Russian, with English summary]

Cotterill F.P.D. 2002. A new species of horseshoe bat (Microchiroptera: Rhinolophidae) from south-central Africa: with comments on its affinities and evolution, and the characterization of rhinolophid species // Journal of Zoology. Vol.256. No.2. P.165-179.

Csorba G., Ujhelyi P. \& Thomas N. 2003. Horseshoe Bats of the World. Shropshire: Alana Books. 160 p. 
Decher J. \& Fahr J. 2003. A conservation assessment of bats (Chiroptera) of Draw River, Boi-Tano, and Krokosua Hills Forest Reserves in the Western Region of Ghana // Myotis. Vol.43. P.5-30.

Demeter A. \& Topal G. 1982. Ethiopian mammals in the Hungarian Natural History Museum // Annales Historico-Naturales Musei Nationalis Hungarici (Budapest). Vol.74. P.331-349.

Fahr J. \& Ebigbo N.M. 2003. A conservation assessment of the bats of the Simandou Range, Guinea, with the first record of Myotis welwitschii (Gray, 1866) from West Africa // Acta Chiropterologica. Vol.5. No.1. P.125-141.

Francis C.M., Kingston T. \& Zubaid A. 2007. A new species of Kerivoula (Chiroptera: Vespertilionidae) from peninsular Malaysia // Acta Chiropterologica. Vol.9. No.1. P.1-12.

Grubb P., Jones T.S., Davies A.G., Edberg E., Starin E.D. \& Hill J.E. 1998. Mammals of Ghana, Sierra Leone and the Gambia. Zennor, Cornwall: The Trendrine Press. 265 p.

Hayman R.W. \& Hill J.E. 1971. Order Chiroptera. // Meester J. \& Setzer H.W. (eds.). The Mammals of Africa. An Identification Manual. Part 2. Washington: Smithsonian Institution Press. P.1-73.

Ivanova N.V., Zemlak T.S., Hanner R.H. \& Hebert P.D.N. 2007. Universal primer cocktails for fish DNA barcoding // Molecular Ecology Notes. Vol.7. P.544-548.

Kalko E.K.V. \& Schnitzler H.-U. 1989. The echolocation and hunting behaviour of Daubenton's bat, Myotis daubentoni // Behavior Ecology and Sociobiology. Vol.24. P.225-238

Kingdon J. 1974. East African Mammals. An Atlas of Evolution in Africa. Vol. II, part A (Insectivores and Bats). London and New York: Academic Press. 340 p.

Kingston T., Jones G., Akbar Z. \& Kunz T. H. 1999. Echolocation signal design in Kerivoulinae and Murininae (Chiroptera: Vespertilionidae) from Malaysia // Journal of Zoology. Vol.249. No.3. P.359-374.

Kock D. 1984. The identity of Nycticejus eriophorus Heuglin 1877 and its status within the Kerivoula lanosa (A. Smith 1847) group (Mammalia: Chiroptera: Vespertili- onidae) // Windhoek: Abstracts of the Fourth International Colloquium on the Ecology and Taxonomy of African Small Mammals. P.20.

Koopman K.F. 1994. Chiroptera: Systematics. Handbuch der Zoology. Mammalia. Vol.VIII (60). Berlin: Walter de Gruyter. 217 p.

Kruskop S. 1999. Ecomorphological diversity of plain-nosed bats (Vespertilionidae, Chiroptera) // Folia Theriologica Estonica. Vol.4. P.1-33.

Largen M.G., Kock D. \& Yalden D.W. 1974. Catalogue of the mammals of Ethiopia. I. Chiroptera // Monitore Zoologico Italiano (N.S.) suppl.5. P.221-298.

Lavrenchenko L.A., Kruskop S.V. \& Morozov P.N. 2004. Notes on the bats (Chiroptera) collected by the Joint Ethiopian-Russian Biological Expedition, with remarks on their systematics, distribution, and ecology // Bonner zoologische Beiträge. Vol.52. P.127-147.

Norberg U.M. 1994. Wing design, flight performance, and habitat use in bats // Wainwright P.C. \& Reilly S.M. (eds.). Ecological Morphology. Integrative Organismal Biology. Chicago: University of Chicago Press. P.205-239.

Norberg U.M. \& Fenton M.B. 1988. Carnivorous bats? // Biological Journal of the Linnean Society. Vol.33. No.4. P.383-394.

Rosevear D.R. 1965. The Bats of West Africa. London: Trustees British Museum (Natural History). xvii+418 p.

Simmons N.B. 2005. Order Chiroptera // Wilson D.E. \& Reeder D.M. (eds.). Mammal Species of the World: A Taxonomic and Geographic Reference, Third Edition. Baltimore: Johns Hopkins University Press. P.312-529.

Schnitzler P.L. \& Kalko E.K.V. 1998. How echolocating bats search and find food // Kunz T.H. \& Racey P.A. (eds.). Bat Biology and Conservation. Washington: Smithsonian Institution Press. P.183-196.

Taylor P.J. 2000. Bats of Southern Africa. Pietermaritzburg: University of Natal Press. 206 p.

Yalden D.W., Largen M.J., Kock D. \& Hillman J.C. 1996. Catalogue of the mammals of Ethiopia and Eritrea. 7. Revised checklist, zoogeography and conservation // Tropical Zoology. Vol.9. P.73-164. 